\title{
水蒸気をキャリヤーガスとしたガスクロマトグラフィーの 医薬品分析への応用
}

I. 日本薬局方製剈中のサリチル酸及びフェノールの定量

\author{
森下宗夫 ${ }^{\circledR ， ~}$ 飯塚英昭*，片柳真佐**，矢島毅彦*
}

(1985 年 10 月 1 日受理)

\begin{abstract}
野中らにより，水蒸気をキャリヤーガスとしたガスクロマトグラフィー（SGG）が提案されて以来， 種々の物質の分離やバターン分析に応用され報告されている. 著者らは SGC 法が水蒸気をキャリヤー ガスに用いることにより，極性物質の誘導体化を省略できる点に着目し，医薬品製刜中の有効成分の 定量を試みた。今回はフェノール及びサリチル酸含有製戍に応用した. カラムに $4 \%$ リン酸処理した Chromosorb P AW を充てえ唷として使用した結果, 安息香酸を内標準物質とし, カラム温度 130〜 $240^{\circ} \mathrm{C}$ (昇温速度 $10^{\circ} \mathrm{G} / \mathrm{min}$ ), 給水量 $10 \mu \mathrm{l} / \mathrm{min}$ で行うと, 保持時間はフェノール 4.0 分, 安息香酸 8.0 分, サリチル酸 10 分であった.フェノールとサリチル酸の安息香酸に対する重量比 $\left(X_{1}, X_{2}\right)$ とピーク高さ比 $\left(Y_{1}, Y_{2}\right)$ の間には, $Y_{1}=2.736 X_{1}-0.006\left(r_{1}=0.996\right), Y_{2}=0.529 X_{2}+0.027\left(r_{2}=0.998\right)$ の回帰式が成立した。 日本薬局方製剤中上記を含む軟こう郕 3 品目及び酒精剤 3 品目につき, その実用 性を検討し，良好な結果が得られた。
\end{abstract}

\section{1 緒 言}

従来のガスクロマトグラフィー (GC) の移動相は一 般に不活性ガスである. その性質上吸着クロマトグラフ 1ーの分離には大きな変化を期待できない。しかし，移 動相に極性の高い水蒸気を用いた場合は，固定相の表面 に和汀吸着作用の変化及び気相中への分配率の変化を 生ずると考兄られており ${ }^{1) 2}$, 分離能への影響が 期待で きる.水溶液試料をはじめとして特に大さな極性を有す る物質, 高沸点化合物を含む水溶液, 寸なわち, 乳液・ 懸濁液の試料にも都合よく利用できる吸着クロマトグラ フィーであることが野中1) 3)及び田中4)により，種々の 物質の分離を例として報告されている.

著者らは医薬品には極性物質が多く, 複合製剂に注射 液を始め水を溶媒とする液剤・乳剤及び軟こう剤など高 沸点化合物を含む製片が多種あることから，水蒸気をキ ヤリヤーガスとしたガスクロマトグラフィー (SGC) に 道応できる可能性が大であることに着目し，本法を GC の有する精度・感度・簡便性に加えて迅速で経済性の高 い実用分析として応用することを目的とし，本実験に取

$*$ 東邦大学薬学部 : 274 千葉県船橋市三山 2-2-1

**三和生薬株式会社：321 杤木県宇都宮市平出工業 団地 1-6
り組んだ。

フェノール及びサリチル酸は角質軟化薬・抗菌薬とし て, 軟こうや液郕に配合され, 第十改正日本薬局方（日 局十) にも 10 数種の含有製剤が収載されているが，定量 法の確立したものは少ないので, その定量を検討した。

\section{2 実験}

\section{1 標準物質及び試料}

標準物質に使用したサリチル酸，フェノール及び安息 香酸は, 和光純薬工業製特級試薬を用いた。

試料としては以下の日局十製剤を用いた，A：サリチ ル酸・カーボン軟こう（処方, サリチル酸 $10 \mathrm{~g}$, 薬用 炭 $10 \mathrm{~g}$, 白色ワセリン $80 \mathrm{~g}), \mathrm{B}:$ サリチル酸・フェノ 一ル軟こう（処方, サリチル酸 $5 \mathrm{~g}$, フェノール $3 \mathrm{~g}$, 白色ワセリン $92 \mathrm{~g}), \mathrm{G}$ : 硫黄 ・サリチル酸・チアント ール軟こう（処方, サリチル酸 $3 \mathrm{~g}$, 硫黄 $10 \mathrm{~g}$, チアン トール $10 \mathrm{~g}$, 酸化亜鉛 $10 \mathrm{~g}$, 白色ワセリン $67 \mathrm{~g}), \mathrm{D}$ : 複方サリチル酸精（処方, サリチル酸 $2 \mathrm{~g}$, フェノール $0.5 \mathrm{~g}$, グリセリン $4 \mathrm{ml}$, エタノール $80 \mathrm{ml}$, 水で全量 を $100 \mathrm{ml}$ とする), $\mathrm{E}:$ ：ウガラシ・サリチル酸精（処 方, サリチル酸 $5 \mathrm{~g}$, フェノール $2 \mathrm{~g}$, トウガラシチン キ $4 \mathrm{ml}$, ヒマシ油 $10 \mathrm{ml}$, エタノールで全量を $100 \mathrm{ml}$ とする), $\mathrm{F}:$ 複方ヨード・トウガラシ精 (処方, 液状

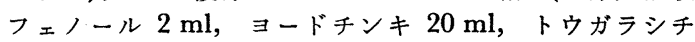
ンキ $10 \mathrm{ml}$, カンフル $5.5 \mathrm{~g}$, サリチル酸メチル $1 \mathrm{ml}$, ヒマシ油 $10 \mathrm{ml}$, エタノールで全量を $100 \mathrm{ml}$ とする) 
なお，以下試料については $\mathrm{A} \sim \mathrm{F}$ の記号を用いる。

\section{2 試料溶液の調製}

サリチル酸を約 $10 \mathrm{mg}$ 以上あるいはフェノールを約 $4 \mathrm{mg}$ 含む試料を精密に採り（軟こう剂はアルミはく上 にとる), エーテル $30 \mathrm{ml}$ に溶解し, 不溶物を認めると きは沪過して除去する，溶解した溶液を $0.2 \mathrm{M}$ 水酸化 ナトリウム溶液 $10 \mathrm{ml}$ で 3 回抽出し, 抽出液を $1 \mathrm{M}$ 塩 酸溶液で酸性とし，エーテル $3 \mathrm{ml}$ 及び $2 \mathrm{ml}$ で 2 回抽 出し, 抽出液を合わせエーテルを留去する，これに内標 準物質として安息香酸 $10 \mathrm{mg}$ を加兄, エタノールを加 えて溶解し, 全量を $10 \mathrm{ml}$ として試料溶液とする.

\subsection{SGC 測定条件}

装置: 大倉理化学研究所製 SSG-1/Model-701 カラム: ガラスカラム, 内径 $2.2 \mathrm{~mm} \times$ 長さ $3 \mathrm{~m}$ 固定相 : Chromosorb P AW 60/80 (4\% リン酸処理) 移動相: 水, 給水量 $10 \mu 1 / \mathrm{min}$ カラム温度 : $130 \sim 240^{\circ} \mathrm{C}$ (昇温速度 : $10^{\circ} \mathrm{C} / \mathrm{min}$ ) 検出器 : 水素フレームイオン化検出器 $\left(250^{\circ} \mathrm{G}\right)$

\section{4 検量線の作成}

試料溶液を上記条件下において SGC の装置に $2 \mu \mathrm{l}$ 注入し, 得られたクロマトグラムの安息香酸のピーク高 さに対する，サリチル酸及びフェノールのピーク高さの 比と安息香酸の重量に対する, サリチル酸及びフェノー ルの重量比を基にした検量線を作成した。

\section{3 結果及び考察}

\subsection{SGG 測定条件の検討}

カラム : 弱酸類の分析用充てん剂としては, 極性の小 さいChromosorb P AW 及び Porasil F が用いられて (るが1) 7)，更に酸の吸着を弱めるため，Chromosorb P AW ４％リン酸処理を行ったものを用いた.

カラム温度と水蒸気流量 : 初めにフェノールの分析条 件及びサリチル酸の分析条件を検討し，内標準物質には いずれも安息香酸を用いて, 水蒸気流量及び カラム温 度の保持時間に対する関係を調べた. その結果フェノー ルの定量については, 軟こう剂の前処理で残存するエー テル及び酒精剤基剤のエタノールとの分離が可能な, カ ラム温度 $140^{\circ} \mathrm{C}$, 給水量 $18.7 \mu \mathrm{l} / \mathrm{min}$ を最適条件とし た. 又サリチル酸の定量については, 内標準物質の安 息香酸との分離を検討し, カラム温度 $200^{\circ} \mathrm{C}$, 給水量 $40 \mu \mathrm{l} / \mathrm{min}$ を最適条件とした。

次にサリチル酸及びフェノールの同時定量の測定条件 を検討した.フェノールの測定条件ではサリチル酸のピ ークが広がり $\{$ Fig. 1（a)\}, サリチル酸の測定条件で (a)

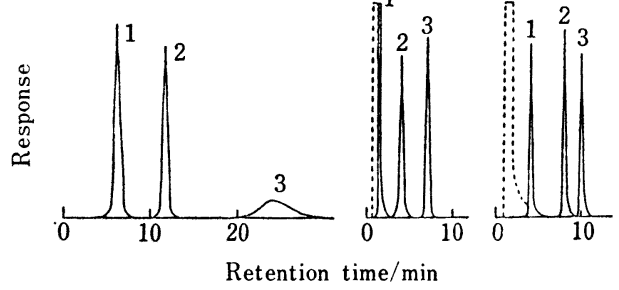

Fig. 1 Chromatograms of a solution containing phenol, salicylic acid and benzoic acid

$1:$ phenol, 2 : benzoic acid, $3:$ salicylic acid, 4 : solvent; (a) : water feeding rate $18.7 \mu \mathrm{l} /$ min, column temp. $140^{\circ} \mathrm{C}$; (b) : water feeding rate $40 \mu \mathrm{l} / \mathrm{min}$, column temp. $200^{\circ} \mathrm{C}$; (c) : water feeding rate $10 \mu \mathrm{l} / \mathrm{min}$, column temp. $130 \sim 240^{\circ} \mathrm{C}\left(10^{\circ} \mathrm{C} / \mathrm{min}\right)$; Column : Chromosorb P AW $60 / 80$ modified with $4 \% \mathrm{H}_{3} \mathrm{PO}$, $2.2 \mathrm{~mm} \phi \times 3 \mathrm{~m}$; Detector : hydrogen flame ionization detection $\left(250^{\circ} \mathrm{C}\right)$

はフェノールが溶媒と分離しなかった $\{$ Fig. 1 (b) $\}$. そこで昇温クロマトグラフィーを検討した．予試験の結 果, 分析温度の差を大さくし, 給水量を小さくしたほら が分離が良いことが認められたので，開始温度 $130^{\circ} \mathrm{C}$, 終了温度 $240^{\circ} \mathrm{C}$, 昇温の割合を 1 分間に $10^{\circ} \mathrm{C}$ とし, 給 水量 $10 \mu \mathrm{l} / \mathrm{min}$ とした. その結果, Fig. 1 (c) に示す ように, 保持時間 4 分にフェノール，8 分に安息香酸, 10 分にサリチル酸の 良好なピークが得られたので，こ の条件を用いることとした.

\section{2 検量線及び定量精度}

本法に扣いては，昇温クロマトグラフィーを行らの で，内標準物質に安息香酸を用いる内標準法とした. 先の測定条件により得られたクロマトグラムより，フェ ノール及びサリチル酸の安息香酸に対する重量比 $\left(X_{1}\right.$, $\left.X_{2}\right)$ とピーク高さ比 $\left(Y_{1}, Y_{2}\right)$ の間にそれぞれ良好な直 線関係式を得た。回帰式は $Y_{1}=2.736 X_{1}-0.006, Y_{2}=$ $0.529 X_{2}+0.027$, 相関係数はそれぞれ $r_{1}=0.996, r_{2}=$ 0.998 であった.

次にクロマトグラムの再現性を検討した. フェノー ル，サリチル酸及び 安息香酸をそれぞれ $4.73 \mathrm{mg}$ ， $10.22 \mathrm{mg}, 10.05 \mathrm{mg}$ 採り, エタノールを加えて溶解し, 全量を $10 \mathrm{ml}$ とした. この溶液の $2 \mu \mathrm{l}$ を注入したとこ ろ, 5 回の繰り返し操作による相対標準偏差は, フェノ ール及びサリチル酸の安息香酸に対するピーク高さ比で それぞれ $0.16 \%, 0.39 \%$ であり，再現性は十分であっ た。 


\section{3 製威の前処理法}

3.3.1 軟こう剤 軟こう剂処方中の軟こう基剤とし ては単軟こう, 白色ワセリンなどが, 又他の共存するも のとしてはチアントール，薬用炭，硫黄及び酸化亜鉛な どが含まれているので，それらの影響を検討した。すず 軟こう剂のらち共存物の少ない試料 $\mathrm{B}$ のエーテル抽出液 について SGGを行った. その結果は Fig. 2(a)で) イズが大きく，フェノール及びサリチル酸のピークを確 認することはできず，共存物の影響の大なることが認め られた. そこでェーテル抽出液を $0.1 \mathrm{M}$ 水酸化ナトリ ウム溶液 $4 \mathrm{ml}$ で 2 回抽出し, 水にて全量を $10 \mathrm{ml}$ とし 検夜 (b) とした. 又試料 Bを別にとり，エーテル抽出液 を $0.1 \mathrm{M}$ 水酸化ナトリウム溶液 $10 \mathrm{ml}$ で 2 回抽出し, 更にそのアルカリ抽出液を $1 \mathrm{M}$ 塩酸で酸性とし, ェー テルにて 2 回抽出後, エーテルを留去し, 残留物をエタ ノールに溶解し，全量を $10 \mathrm{ml}$ とし検液（c) とした．検 液 $(\mathrm{b})$ 及び $(\mathrm{c})$ のそれぞれ $2 \mu \mathrm{l}$ を注入して得られたク ロマトグラムは Fig. 2(b) 及び (c)である. 検液 (b) にはノイズが見られるが，検液 $(\mathrm{c})$ に比較してピーク高 さに差はなかった．従って軟こう剂の前処理としては, アルカリ抽出する (b)かもしくは更に操作を進めてェー テル抽出する $(\mathrm{c})$ かどちらかを採用することとした. (a)

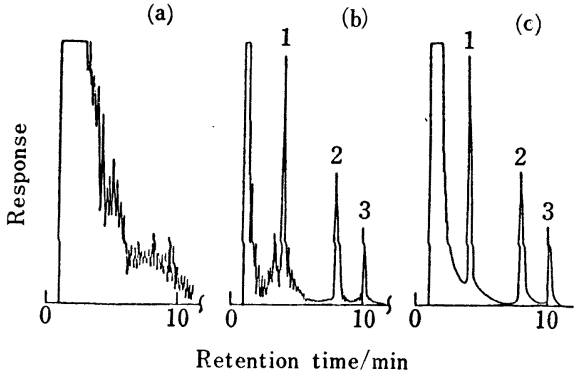

Fig. 2 Comparison of methods for preparation of a test solution from an ointment

1 : phenol, 2 : benzoic acid, 3 : salicylic acid; (a) : ether extract, (b) : alkaline extract, (c): ether extract of acidified alkaline extract. The conditions are the same as in Fig. 1 (c). For preparation of test solutions, see the text.

次にこの操作の再現性を調べる目的で回収実験を行っ た. 方法は初めに白色ワセリン及び単軟こうそれぞれ $0.1 \mathrm{~g}$ をアルほく上に量り取り, 更にサリチル酸 10 $\mathrm{mg}$ 及びフェノール $4 \mathrm{mg}$ を精密に量り取る.よく混和 後アルミはくごと分液漏斗に移し, 前述の抽出操作を行 った. 安息香酸を抽出液に加えそれぞれ全量を $10 \mathrm{ml}$ と

し，検液 $(\mathrm{b})$ 及び $(\mathrm{c})$ とした. 5 回繰り返しの回収率の 平均值及び相対標準偏差を Table 1 に示した. その結 果回収率に差を認めなかった. しかしカラム維持の目的 からは検液 (c)の調製法を採用することが望ましい.

Table 1 Recovery test of salicylic acid and phenol from ointment

\begin{tabular}{|c|c|c|c|c|}
\hline \multirow{2}{*}{ Compound } & \multicolumn{2}{|c|}{$\underset{\text { (b) }}{\text { Alkaline extract }}$} & \multicolumn{2}{|c|}{$\begin{array}{l}\text { Ether extract of } \\
\text { acidified alkaline } \\
\text { extract (c) }\end{array}$} \\
\hline & $\begin{array}{c}\text { Recovery, } \\
\%\end{array}$ & $\underset{\%}{\text { R.S.D., }}$ & $\underset{\%}{\text { Recovery, }}$ & R.S.D., \\
\hline Salicylic acid & 99.4 & 0.80 & 99.3 & 0.59 \\
\hline Phenol & 99.2 & 0.72 & 99.4 & 0.59 \\
\hline
\end{tabular}

3.3.2 酒精剈 酒精剂処方中に共存するヒマシ油, トウガラシチンキ，グリセリン，カンフル及びサリチル 酸メチルなどの影響を検討した。酒精剂の $0.2 \sim 0.5 \mathrm{ml}$ を正確に量り, エーテル $10 \mathrm{ml}$ を加え, $0.1 \mathrm{M}$ 水酸化 ナトリウム溶液 $4 \mathrm{ml}$ で 2 回抽出し, 水にて 全量を 10 $\mathrm{ml}$ とし検液（a)とした。 以下軟こう剂に準じて操作を 行い検液 $(\mathrm{b})$ とした．検液 $(\mathrm{a})$ 及び検液 $(\mathrm{b})$ のそれぞれ $2 \mu l$ を注入して得られたクロマトグラムは, Fig. 3(a)， (b) である.

これらの結果は, 酒精剤は軟こら剤におけるよりも調 製法などによる差を認めないことを示すものである。し かし前述同様カラム維持の目的からは検液 (b)の調製法 を採用することが望ましい。

(a)

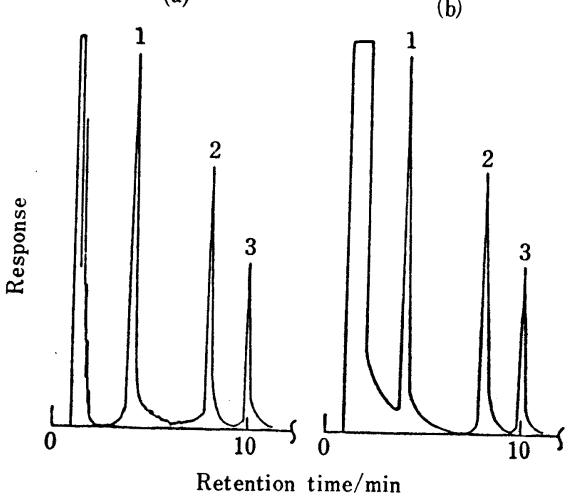

Fig. 3 Comparison of methods for preparation of a test solution from a spirit

1 : phenol, 2 : benzoic acid, 3 : salicylic acid; (a) : alkaline extract, (b) : ether extract of acidified alkaline extract. The conditions are the same as in Fig. 1 (c). For preparation of test solutions, see the text. 


\section{4 製剤中のフェノール及びサリチル酸の定量}

薬局方製剤中フェノール及びサリチル酸含有製剤の分 析を行った．製剤試料中軟こう剂である $\mathrm{A} ， \mathrm{~B}$ 及び $\mathrm{C} に$ ついては 0.1 0.4 g を精密に量り, 又酒精剤である $\mathrm{D}$,

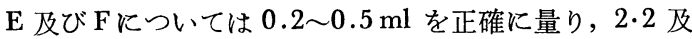
び 2.4 に従って操作し, 試料溶液を調製後定量を行っ た. 各試料につき 5 回分析した結果を, Table 2 及び Table 3 に示した. その際それぞれの試料の分析で得 たクロマトグラムにはフェノール，サリチル酸及び安息

Table 2 Determination of phenol and salicylic acid in ointments

\begin{tabular}{|c|c|c|c|c|c|c|c|}
\hline \multicolumn{4}{|c|}{ Taken/ $\mu g$} & \multicolumn{2}{|c|}{ Found/ $\mu \mathrm{g}$} & \multicolumn{2}{|c|}{ R.S.D., \% } \\
\hline Oin & tments & $\mathrm{P}$ & $\widehat{\text { SA }}$ & $\mathrm{P}$ & $\widehat{\mathrm{SA}}$ & $\mathrm{P}$ & $\widehat{S A}$ \\
\hline A & $\begin{array}{l}33.4 \\
24.6 \\
27.8 \\
26.2 \\
31.0\end{array}$ & - & $\begin{array}{l}3.52 \\
2.58 \\
2.92 \\
2.76 \\
3.26\end{array}$ & - & $\begin{array}{l}3.46 \\
2.50 \\
2.88 \\
2.68 \\
3.20\end{array}$ & - & 0.78 \\
\hline B & $\begin{array}{l}33.6 \\
35.2 \\
31.6 \\
34.8 \\
29.6\end{array}$ & $\begin{array}{l}1.048 \\
1.098 \\
0.986 \\
1.086 \\
0.924\end{array}$ & $\begin{array}{l}1.832 \\
1.918 \\
1.722 \\
1.896 \\
1.614\end{array}$ & $\begin{array}{l}1.064 \\
1.096 \\
0.994 \\
1.112 \\
0.920\end{array}$ & $\begin{array}{l}1.884 \\
1.948 \\
1.736 \\
1.936 \\
1.632\end{array}$ & 1.16 & 0.78 \\
\hline $\mathrm{C}$ & $\begin{array}{l}67.0 \\
73.6 \\
66.0 \\
69.0 \\
66.6\end{array}$ & - & $\begin{array}{l}2.052 \\
2.254 \\
2.020 \\
2.112 \\
2.040\end{array}$ & - & $\begin{array}{l}2.022 \\
2.240 \\
1.998 \\
2.080 \\
2.048\end{array}$ & - & 0.80 \\
\hline
\end{tabular}

P : phenol; SA : salicylic acid; A : salicylated carbon ointment (Rp. salicylic acid $10 \mathrm{~g}$, medicinal carbon $10 \mathrm{~g}$, white petrolatum $80 \mathrm{~g}$ ); B : salicylated phenol ointment (Rp. salicylic acid $5 \mathrm{~g}$, phenol $3 \mathrm{~g}$, white petrolatum $92 \mathrm{~g}$ ); $\mathrm{C}$ : sulfur, salicylic acid and thianthol ointment (Rp. salicylic acid $3 \mathrm{~g}$, sulfur $10 \mathrm{~g}$, thianthol $10 \mathrm{ml}$, zinc oxide $10 \mathrm{~g}$, white petrolatum $67 \mathrm{~g}$ )

Table 3 Determination of phenol and salicylic acid in spirits

\begin{tabular}{|c|c|c|c|c|c|c|c|}
\hline \multicolumn{4}{|c|}{ Taken/ $\mu \mathrm{g}$} & \multicolumn{2}{|c|}{ Found/ $\mu \mathrm{g}$} & \multicolumn{2}{|c|}{ R.S.D., \% } \\
\hline Spiri & ts $(\mu l)$ & $\mathrm{P}$ & SA & $\mathrm{P}$ & SA & $\mathrm{P}$ & $\widehat{\mathrm{SA}}$ \\
\hline $\mathrm{D}$ & 0.04 & 0.644 & 1.944 & 0.648 & 1.969 & 0.83 & 0.97 \\
\hline $\mathrm{E}$ & 0.04 & 0.834 & 1.986 & 0.832 & 2.008 & 1.19 & 0.86 \\
\hline$F$ & 0.04 & 0.730 & - & 0.725 & - & 0.47 & - \\
\hline
\end{tabular}

P : phenol; SA : salicylic acid; D : compound salicylic acid spirit (Rp. salicylic acid $2 \mathrm{~g}$, phenol $0.5 \mathrm{~g}$, glycerol $4 \mathrm{ml}$, ethanol $80 \mathrm{ml}$, filled up to $100 \mathrm{ml}$ with water); E : capsicum and salicylic acid spirit (Rp. salicylic acid $5 \mathrm{~g}$, phenol $2 \mathrm{~g}$, capsicum tincture $4 \mathrm{ml}$, castor oil $10 \mathrm{ml}$, filled up to $100 \mathrm{ml}$ with ethanol); F : compound iodine and capsicum spirit (Rp. phenol $2 \mathrm{ml}$, iodine tincture $20 \mathrm{ml}$, capsicum tincture $10 \mathrm{ml}$, $d$ - or $d l$-camphor $5.5 \mathrm{~g}$, methyl salicylate $1 \mathrm{ml}$, castor oil $10 \mathrm{ml}$, filled up to $100 \mathrm{ml}$ with ethanol). The data were obtained after five runs.
香酸を妨害するピークは認められなかった．定量値は同 一試料での測定において，ばらつきが少なく十分実用可 能であることを示した.

又試料中 $\mathrm{F}$ はフェノールのみ， $\mathrm{A}$ 及び $\mathrm{C}$ はサリチル酸 のみを含む試料であり，これらの各試料については，3.1 に示した測定条件（フェノールの測定条件：カラム温度 $140^{\circ} \mathrm{C}$, 給水量 $18.7 \mu \mathrm{l} / \mathrm{min}$; サリチル酸の 測定条件 : カラム温度 $200^{\circ} \mathrm{C}$, 給水量 $40 \mu \mathrm{l} / \mathrm{min}$ ) で分析を行っ た. 試料溶液の調製は上記同様に行い, 各試料につき 5 回分析した結果を Table 4 に示した. 先の同時定量カ ラム条件の結果に比較してばらつきが小さく，昇温に不 可欠な温度の回復を待つ必要がなく，分析時間を短縮で きる. 従ってフェノールあるいはサリチル酸のいずれか 一方を含む場合には，それぞれを定温で分析するほうが 良い定量值を得ることを認めた。な敃この方法における 検量線の回帰式は，フェノール及びサリチル酸の安息香 酸に対する重量比を $X_{1}$ 及び $X_{2}$, ピーク高さ比を $Y_{1}$ 及び $Y_{2}$ とすると，それぞれ $Y_{1}=3.174 X_{1}+0.052 ， Y_{2}$ $=0.477 X_{2}-0.003$ であり，相関係数はそれぞれ $r_{1}=$ 0.9993 及び $r_{2}=0.9992$ であった.

Table 4 Determination of phenol or salicylic acid in pharmaceutical preparations

\begin{tabular}{|c|c|c|c|c|}
\hline \multicolumn{3}{|c|}{ Sample taken $/ \mu \mathrm{g}$} & \multirow{2}{*}{$\underset{\mu \mathrm{g}}{\text { Found/ }}$} & \multirow{2}{*}{$\underset{\%}{\text { R.S.D., }}$} \\
\hline Prep & aration & Pheonl or Salicylic acid & & \\
\hline \multicolumn{4}{|c|}{ (Salicylic acid) } & \multirow[b]{2}{*}{0.54} \\
\hline A & $\begin{array}{l}25.6 \\
28.0 \\
27.0 \\
28.8 \\
27.6\end{array}$ & $\begin{array}{r}2.69 \\
2.94 \\
2.84 \\
3.03 \\
2.90\end{array}$ & $\begin{array}{l}2.68 \\
2.95 \\
2.85 \\
3.01 \\
2.88\end{array}$ & \\
\hline \multicolumn{4}{|c|}{ (Salicylic acid) } & \multirow[b]{2}{*}{0.39} \\
\hline $\mathrm{C}$ & $\begin{array}{l}70.4 \\
65.6 \\
64.8 \\
66.4 \\
67.0\end{array}$ & $\begin{array}{r}2.156 \\
2.009 \\
1.984 \\
2.033 \\
2.051\end{array}$ & $\begin{array}{l}2.151 \\
2.000 \\
1.991 \\
2.034 \\
2.038\end{array}$ & \\
\hline \multicolumn{3}{|c|}{ (Phenol) } & & \\
\hline $\mathrm{F}$ & $0.04 \mu 1$ & $0.730 \mu l$ & $\begin{array}{l}0.728 \mu l \\
0.726^{\prime \prime} \\
0.730 " \\
0.728^{\prime \prime} \\
0.732^{\prime \prime}\end{array}$ & 0.31 \\
\hline
\end{tabular}

A, C, F : Tables 2, 3.

以上，本法においては従来の GG では不可能である アルカリ抽出液の直接注入により良好な結果を得た。こ のことから前処理操作が簡便ですみ, 分析所要時間が短 縮でき, 多数試料の分析に適する点から,フェノール及 びサリチル酸を含有する製剤分析に実用し得る方法であ ることが認められた。 


\section{交献}

1) 野中 昭: “水蒸気キャリアーガス気一固クロマト グラフィー”, (1976), (応用光学研究所).

2) 野中 昭: 分化, 17, 944 (1968).

3) 野中 昭: 分化, 20, 422 (1971).

4) 田中多美穂: 油化学, 30, 51 (1981).

5) 野中 昭: 分化, 16, 1166 (1967).

6) 野中 昭: 分化, 17, 91 (1968).

7) 野中 昭：分化, 17, 1215 (1968).

is

Application of steam carrier gas chromatography to analyses of pharmaceuticals; 1 . Determination of salicylic acid and phenol in pharmaceutical preparations in the Japanese Pharmacopoeia X. Muneo Morishita, Hideaki IrzukA*, Masa Katayanagi** and Takehiko Yajima* (*School of Pharmaceutical Science, Toho University, 2-2-1, Miyama, Funabashi-shi, Chiba 274; **Sanwa Shoyaku Co., Ltd., 1-6, Hiraide Kogyodanchi, Utsunomiya-shi, Tochigi 321)

The determination method of phenol and salicylic acid in pharmaceutical preparations was investigated by using adsorption chromatography with steam as a carrier, the temperature of which was more than $100^{\circ}$ C. Chromosorb P AW (60 80 meshes) modified with $4 \%$ phosphoric acid was employed as a stationary phase. With benzoic acid as an internal standard, both phenol and salicylic acid were able to be deter- mined quantitatively without interference by moisture in samples or solvent alcohol under the following conditions: for phenol, column temperature, $140^{\circ} \mathrm{C}$ and water feeding rate, $18.7 \mu \mathrm{l} / \mathrm{min}$; for salicylic acid, column temperature, $200^{\circ} \mathrm{C}$ and water feeding rate, 40 $\mu \mathrm{l} / \mathrm{min}$. Simultaneous determination of phenol and salicylic acid was performed by raising the column temperature at a rate of $10^{\circ} \mathrm{C} / \mathrm{min}$ from $130^{\circ} \mathrm{C}$ to 240 ${ }^{\circ} \mathrm{C}$ and at the water feeding rate of $10 \mu \mathrm{l} / \mathrm{min}$. Benzoic acid was also used as an internal standard for the simultaneous determination. Following results were obtained by the regression analysis of the weight ratio $\left(X_{1}, X_{2}\right)$ and the peak height ratio $\left(Y_{1}, Y_{2}\right)$ between phenol or salicylic acid and benzoic acid: regression equations, $Y_{1}=2.736 X_{1}-0.006$ and $Y_{2}=0.529 X_{2}+0.027$; correlation coefficients, $r_{1}=0.996$ and $r_{2}=0.998$; relative standard deviations after five runs, $0.16 \%$ for $Y_{1}$ and $0.39 \%$ for $Y_{2}$. These data indicate that the present method is good enough for quantitative analysis. Under the conditions mentioned above, six pharmaceuticals specified in JPX were successfully analyzed quantitatively.

(Received October 1, 1985)

\section{Keyword phrases}

steam carrier gas chromatography; determination of salicylic acid and phenol; pharmaceutical preparation. 